\title{
Menanamkan Jiwa Kewirausahaan melalui Percontohan Budidaya Tanaman Pangan pada Anak Usia Sekolah di Kabupaten Minahasa Utara
}

\author{
Verra E. J. Mawitjere ${ }^{1}$, Revolson A. Mege ${ }^{2}$, Julduz R. Paus ${ }^{3}$, Jeane Mantiri ${ }^{4}$, Mokosuli Y. Semuel ${ }^{5}$ \\ $1,2,3,4,5$ Universitas Negeri Manado
}

\begin{abstract}
A community service activity through the Community Empowerment program (KKN PPM) to improve school-age children's entrepreneurship skills and knowledge in Likupang Barat has been well implemented. The KKN PPM program aims to produce an action program for food crop cultivation by utilizing the schoolyard in an effort to instill the entrepreneurial spirit in school-age children and increase knowledge and skills in life skills through pilot projects of cultivation of food crops for school-age children in SMPN 1 Talise. The method used in the KKN PPM program was a combination of "application of science and technology appropriately" in cultivation of food crops with the "Pilot Project" learning approach or demonstration of farming by utilizing the schoolyard. Therefore, the children get life skill experience in the effort to characterize entrepreneurship. Moreover, this activity becomes a laboratory and learning resource for students of the Economic Education subjects as well as child character development. The results achieved in this program were the availability of the piloting food crops that can support the fulfillment of consumption needs. In addition, it can be used as a learning media for the Economic Education subject in an effort to instill an entrepreneurial spirit, as well as a source of school needs for school-aged children.
\end{abstract}

Keywords: entrepreneurship, crop cultivation, school-age children

\section{PENDAHULUAN}

Salah satu permasalahan mendasar yang dihadapi bangsa Indonesia dan khususnya di Provinsi Sulawesi Utara saat ini adalah rendahnya serapan lulusan Sekolah Menengah Atas (SMA) maupun Sekolah Menengah Kejuruan (SMK) dalam dunia kerja yang berimplikasi pada peningkatan angka kerja dari tahun ke tahun. Peningkatan angka kerja tersebut disumbangkan juga oleh tingginya lulusan Sekolah Menengah Pertama (SMP) dan Sekolah Dasar (SD). Peningkatan angka kerja tersebut tidak sebanding dengan ketersediaan lapangan kerja. Berdasarkan data Statistik bulan Februari 2018 menunjukkan bahwa jumlah 131 juta angkatan kerja terdiri dari pendidikan SD 59,6\%, SMP 16,78\%, SMA $3 \%$, pendidikan SMK 11,34\%, pendidikan diploma $3 \%$, serta lulusan perguruan tinggi 9\% (Data Dinas Pendidikan, 2018). Hal ini antara lain diduga disebabkan karena kecenderungan proses pembelajaran di sekolah yang proporsinya lebih menekankan pada penguasaan ilmu pengetahuan dan teknologi pada skala laboratorium dan sangat sedikit memberikan pengalaman kepada siswa mengenal dunia nyata (kerja) yang pada gilirannya membentuk motivasi orientasi lulusan menjadi pencari kerja, bukan menciptakan lapangan kerja dan kurangnya jiwa berwirausaha. Sesungguhnya bekal ilmu pengetahuan dan teknologi yang dimiliki siswa potensial untuk dikembangkan dan diterapkan dalam dunia kerja terlebih menciptakan lapangan kerja atau berwirausaha. Namun minimnya pengalaman praktis dalam mengaplikasikan ilmu pengetahuan dan teknologi serta pengalaman berwirausaha yang dimiliki menjadikan motivasi orientasi dan keberanian berwirausaha tidak tumbuh. Permasalahan tingginya angka pengangguran terjadi juga di Talise Kecamatan Likupang Barat. Jumlah pengangguran tidak saja disumbangkan oleh anak-anak yang telah lulus tetapi juga oleh anak-anak yang putus sekolah atau tidak dapat melanjutkan pendidikan pada jenjang selanjutnya. Hal ini tergambar dari data tahun 2010 sebanyak 8 orang anak (10,13\%) dari 79 lulusan Sekolah Dasar 
di Kecamatan Likupang Barat yang tidak dapat melanjutkan ke Sekolah Menengah Pertama (SMP) Negeri Satu Likupang Barat di Talise meningkat pada tahun 2013 menjadi 12 orang anak (13,95\%) dari 86 siswa lulusan SD yang tidak dapat melanjutkan studi ke SMP. Lebih tragis lagi angka anak putus sekolah khususnya di SMP Negeri Satu Likupang Barat juga terus meningkat. Hal ini terlihat pada data dimana pada tahun 2010 mencapai 5 orang anak putus sekolah, dan meningkat pada tahun 2014 mencapai 13 orang anak (Data Dinas Pendidikan, 2018). Berangkat dari permasalahan tersebut di atas maka salah satu cara yang efektif atau solusi mengatasi masalah pengangguran yaitu merubah proses pembelajaran yang dapat membentuk motivasi orientasi lulusan yang selama ini sebagai "pencari kerja" menjadi "pencipta lapangan kerja" atau membentuk jiwa berwirausaha yang ditanamkan sejak usia dini antara lain melalui pembekalan diri dalam hal keterampilan dan pengalaman nyata pada anak usia sekolah. Selanjutnya melihat peluang dan potensi yang tersedia secara lokal di Talise, maka selayaknya siswa dibimbing dan diperkenalkan pada konsep berwirausaha budidaya tanaman pangan.

Alasan lain juga dipilih budidaya tanaman pangan sebagai model pemberdayaan masyarakat khususnya anak usia sekolah yaitu bertolak dari fakta selama ini sebagian kebutuhan konsumsi pangan bagi masyarakat pemukim pulau-pulau kecil di Kecamatan Likupang Barat setiap minggu yang mencapai 650 - $750 \mathrm{~kg}$ dipasok dari daratan Minahasa maupun Minahasa Utara melalui pelabuhan laut Likupang yang tentunya dengan harga tidak murah lagi. Seharusnya apabila usaha tanaman pangan di pulau Talise dapat dikembangkan sendiri oleh masyarakat, di samping dapat meningkatkan pendapatan ekonomi, juga dapat menyediakan kebutuhan pangan yang lebih murah dan sehat bagi masyarakat di Talise maupun bagi pemukim empat pulau tetangga lainnya.

Memahami kompleksnya permasalahan yang dihadapi masyarakat khususnya dalam upaya mengatasi masalah pengangguran di Kecamatan Likupang Barat, dan sebagai perwujudan dari misi tridharma Perguruan Tinggi, maka Lembaga
Pengabdian Kepada Masyarakat Universitas Negeri Manado terpanggil memberikan solusi memecahkan masalah tersebut melalui kegiatan Kuliah Kerja Nyata Pembelajaran Pemberdayaan Masyarakat (KKN PPM). Dalam kegiatan ini pelaksana KKN PPM mengaplikasikan dan mengembangkan ilmu pengetahuan dan teknologi yang dikuasai untuk menyelesaikan permasalahan yang ada di tengah masyarakat khususnya anak usia sekolah. Seperti yang diungkapkan oleh Mulyasa dikatakan bahwa suatu proses pembelajaran pada intinya dimaksudkan untuk mengembangkan aktivitas serta kreativitas peserta didik melalui berbagai pengalaman, maka solusi yang dilaksanakan adalah memberdayakan anak usia sekolah melalui kecakapan hidup (life skill) tentang budidaya tanaman pangan dengan memanfaatkan halaman sekolah di samping memberikan nilai ekonomi dan pengalaman nyata life skill, juga menjadi satu media pembelajaran nyata dalam upaya memberikan pengetahuan, pengalaman dan keterampilan praktis bagi anak usia sekolah untuk berwirausaha (Mulyasa, 2008).

\section{METODE KEGIATAN}

Sebagaimana diuraikan sebelumnya bahwa dalam rangka mengatasi permasalahan yang dihadapi oleh kelompok masyarakat sasaran (anak usia sekolah) maka metode pendekatan yang akan diterapkan adalah menggunakan metode "tepat guna" aplikasi ilmu pengetahuan dan teknologi integrasi pendekatan pembelajaran "Scientific" dan "Pilot Project" budidaya tanaman pangan dengan memanfaatkan halaman sekolah, sehingga di samping anak-anak mendapatkan pengalaman life skill, juga tertanam jiwa kewirausahaan sejak dini sekaligus membina karakter anak. Dalam kepedulian mengembangkan dunia usaha, setidaknya Indonesia harus memiliki 3 juta wirausahawan besar dan 30 juta wirausahawan kecil (Alma, 2013). Menurut Harper, pertumbuhan ekonomi suatu bangsa yang berkembang seperti halnya Indonesia, dapat berjalan dengan baik bilamana dirangsang dengan aktivitas kewirausahaan (Maramis, Mege, Saerang, \& Manopo, 2016). 
Aktivitas utama mahasiswa KKN PPM yaitu melakukan sosialisasi dan proses pembelajaran dalam uaya transformasi ilmu pengetahuan dan teknologi untuk memecahkan masalah yang dihadapi oleh masyarakat sasaran yaitu pemenuhan kebutuhan pangan baik untuk konsumsi maupun untuk mendapatkan nilai ekonomi yang dapat mengatasi masalah pendidikan anak. Langkah selanjutnya mahasiswa KKN PPM mengedukasi melalui proses pembelajara langsung di lapangan dan mendampingi siswa dalam rangkaian proses budidaya tanaman pangan (jagung, cabai, tomat dan sayuran) mulai dari pembenihan, persiapan bedengan, pembuatan pupuk organik, pemeliharan dan penanganan pascapanen.

\section{HASIL YANG DICAPAI}

Suatu kegiatan pengabdian kepada masyarakat melalui Program Kuliah Kerja Nyata Pembelajaran Pemberdayaan Masyarakat (KKN PPM) telah dilaksanakan di Desa Talise dengan kelompok sasaran adalah anak usia sekolah khususnya siswa SMP Negeri 1 Talise telah terlaksana dengan baik. Pelaksnaan program KKN PPM memiliki makna ganda yaitu di samping sebagai salah satu upaya mengimplementasikan misi tridharma Perguruan Tinggi, juga secara spesifik sebagai wahana untuk mengaplikasikan ilmu pengetahuan, teknologi dan keterampilan kepada masyarakat, serta pembelajaran bagi mahasiswa mengenal dan memecahkan permasalahan di tengah rmasyarakat terutama dalam membentuk jiwa kewirausahaan pada anak usia sekolah. Kegiatan KKN PPM ini diawali oleh serangkaian kegiatan survey dan sosialisasi di SMP Negeri 1 Talise dalam upaya menyampaikan halhal yang berkaitan dengan program KKN PPM untuk mengatasi masalah yang dihadapi masyarakat serta teknologi yang diterapkan melalui kehadiran mahasiswa peserta KKN PPM. Dalam tahapan sosialisasi ini pula telah tercipta komunikasi yang harmonis antara pelaksana KKN PPM dengan masyarakat sasaran khususnya guru-guru dan siswa SMP Negeri 1 Talise.

Selanjutnya untuk mengatasi permasalahan tersebut di atas, maka dirancang program $\mathrm{KKN}$
PPM untuk memberikan pembelajaran pemberdayaan kepada masyarakat terutama merubah motivasi orientasi lulusan dalam upaya menekan angka pengangguran yang dari waktu ke waktu terus mengalami peningkatan. Salah satu langkah yang dapat dilakukan adalah menanamkan jiwa kewirausahaan sejak usia dini atau sekolah, sehingga kelak tamat sekolah (SMP maupun SMA/SMK) maka lulusan tersebut ketika tidak dapat melanjutkan pendidikan formal pada jenjang selanjutnya, mereka telah mendapatkan pengalaman nyata terutama telah tumbuh jiwa berwirausaha. Dalam upaya menanamkan jiwa kewirausahaan terhadap siswa sejak usia sekolah, maka melalui Program KKN PPM telah difasilitasi melalui program aksi proses pembelajaran dan pendampingan berwirausaha anak usia sekolah dalam hal ini bagi siswa SMP Negeri 1 Talise melalui program Life Skill budidaya tanaman pangan dengan halaman sekolah yang yang mencapai 2 ha. Pemanfaatan halaman sekolah selain dalam upaya menunjang upaya pemenuhan kebutuhan dan menyediakan konsumsi pangan yang sehat dan murah, juga bagi siswa selain mendapatkan pengalaman nyata berwirausaha dimana siswa secara langsung terlibat secara aktif mulai dari proses produksi sampai pasca panen dan mengelola langsung hasil dari penjualan yang diperoleh, juga siswa telah mendapatkan pengalaman nyata mendapatkan penghasilan dan tercipta sumber pendapatan yang dapat membantu siswa mengatasi kebutuhan belajar dan kebutuhan lainnya. Secara keseluruhan proses pelaksanaan kegiatan KKN PPM ini dijalankan dan dikerjakan oleh mahasiswa bersama masyarakat. Khusus pelaksanaan KKN PPM di SMP Negeri 1 Talise selain melibatkan siswa, dan guru-guru, juga masyarakat sekitar dan terutama orang tua murid.

Sebagaimana diuraikan sebelumnya bahwa program KKN PPM ini dilaksanakan untuk mencapai tujuan yang bertolak dari permasalahan yang ada. Oleh karena itu dalam upaya mengatasi rendahnya pengetahuan dan keterampilan masyarakat, maka pada saat penerimaan yang bersamaan dengan upacara adat mensyukuri/melepas tahun lama, langsung dilaksanakan juga sosialisasi dan 
pemaparan materi dalam upaya peningkatan peningkatan pengetahuan dan keterampilan usaha tani tanaman pangan berupa budidaya tanaman pangan (cabai, tomat, kacang tanah, jagung dan sayuran. Kegiatan tersebut selain dihadiri oleh masyarakat, juga dihadiri oleh Kepala Wilayah Kecamatan Likupang Barat, Kepala Desa (Hukum Tua) bersama perangkat desa Talise.

Oleh karena itu, dalam rangka mengatasi masalah terkait dengan usaha pertanian tanaman pangan, maka melalui program KKN PPM ini telah pula terfasilitasi serangkaian kegiatan mulai dari penyuluhan sampai dengan pendampingan berupa penanaman jagung dan sayuran serta kacangkacangan yang dilakukan oleh masyarakat maupun oleh anak-anak siswa SMP di Talise. Demikian halnya dengan komoditi tanaman pangan, melalui kegiatan mahasiswa KKN PPM bersama masyarakat telah terfasilitasi usaha tani tanaman pangan terutama tanaman cabai dan tomat serta sayuran, yang ditargetkan komoditi-komoditi tersebut mulai panen pada saat hari raya idul fitri. Hal ini memberi gambaran bahwa kegiatan tersebut telah memberi makna ganda yaitu selain masyarakat mendapatkan pengetahuan dan keterampilan, juga sangat membantu dalam upaya pemenuhan kebutuhan konsumsi pangan yang murah dan mudah didapat.

Sebagaimana diuraikan sebelumnya bahwa usaha budidaya tanaman pangan di halaman sekolah, bagi sekolah selain bertujuan menjadi media pembelajaran sains dengan pendekatan scientific, juga menjadi media bagi siswa untuk pendidikan kewirausahaan, yang melatih siswa belajar berusaha, juga membentuk karakter siswa. Sementara bagi masyarakat desa Talise khususnya permukim di dusun II, usaha tersebut terutama bertujuan untuk memenuhi kebutuhan konsumsi maupun untuk meningkatkan pendapatan masyarakat. Dalam kegiatan ini masyarakat telah dituntun dan didamping oleh mahasiswa peserta KKN PPM maupun dalam setiap proses kerja usaha tani. Dalam kegiatan ini masyarakat telah dituntun secara teori tentang budidaya masing-masing tanaman pangan yaitu dari proses pembenihan sampai dengan proses produksi dan penanganan pasca panen. Dalam hal ini suatu pengalaman yang konkret dan dinamis merupakan alat untuk menyusun suatu pengertian yang sederhana, sehingga pengalaman yang ada dapat ditiru untuk diulangi. Para siswa memperoleh pengertian yang umum dengan pasti dan lebih baik disebabkan oleh contoh-contoh sederhana. Suatu konteks pembelajaran sederhana tetapi diberikan melimpah akan memberikan suatu pekerjaan dan kesempatan untuk mengadakan percobaan atau eksperimen yang cukup bagi para siswa (Slameto, 2010).

Rangkaian praktek budidaya tanaman pangan untuk menumbuhkan jiwa berwirausaha pada siswa terlihat pada gambar berikut.

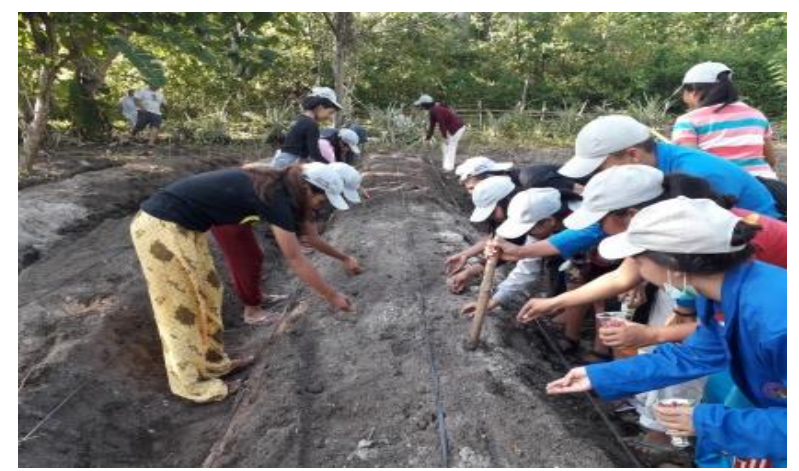

Gambar 1. Pendampingan guru-guru

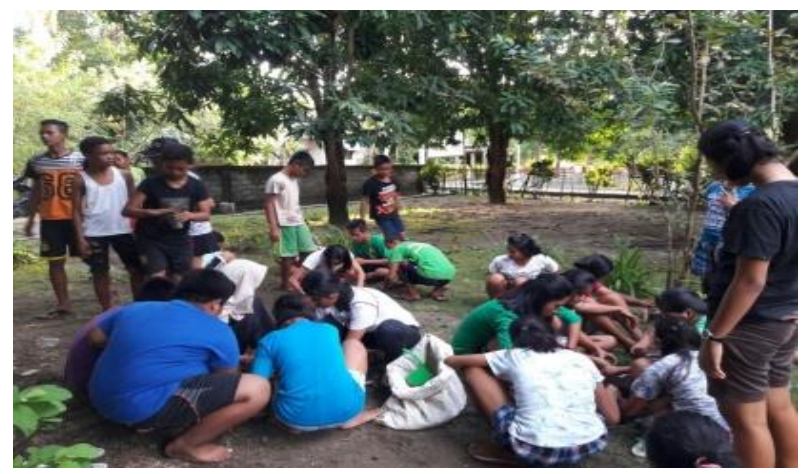

Gambar 2. Bimbingan semai benih

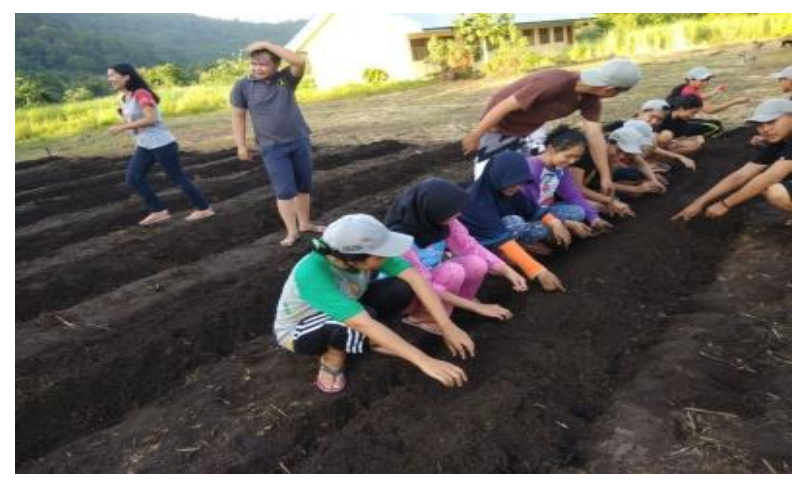

Gambar 3. Praktek pembuatan bedengan 


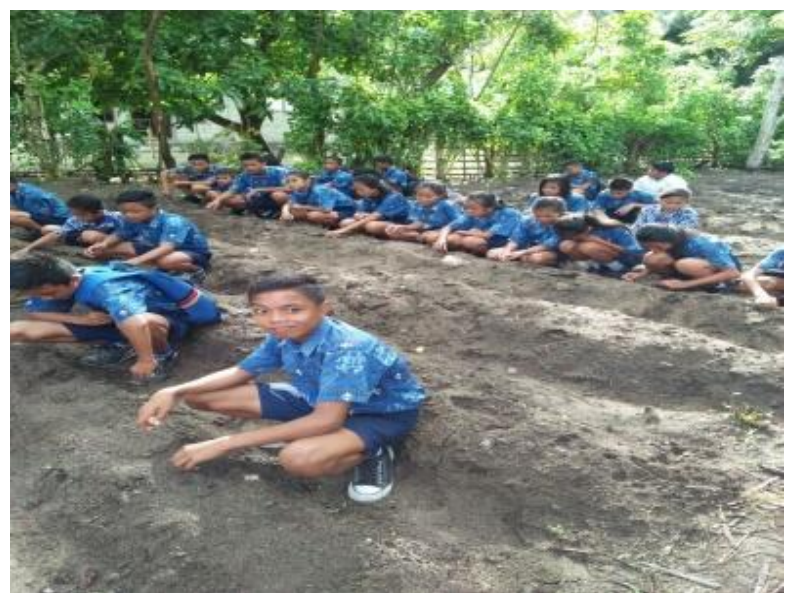

Gambar 4. Pembimbingan siswa

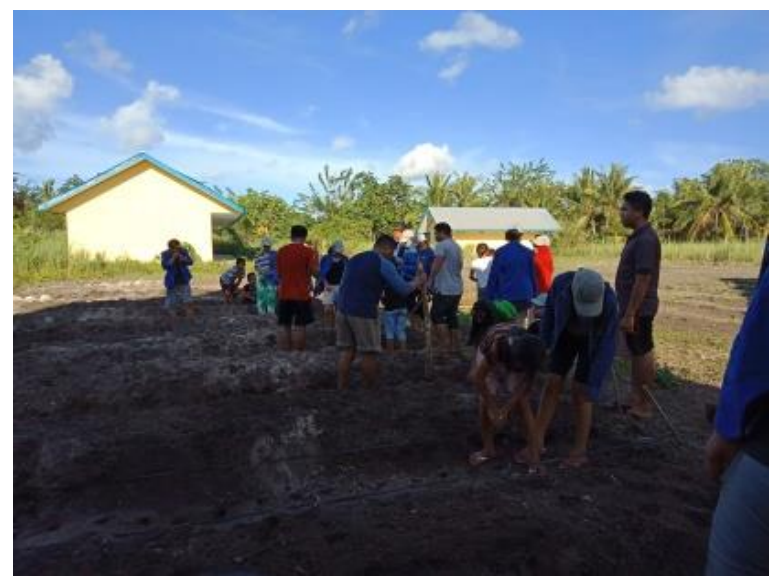

(a)

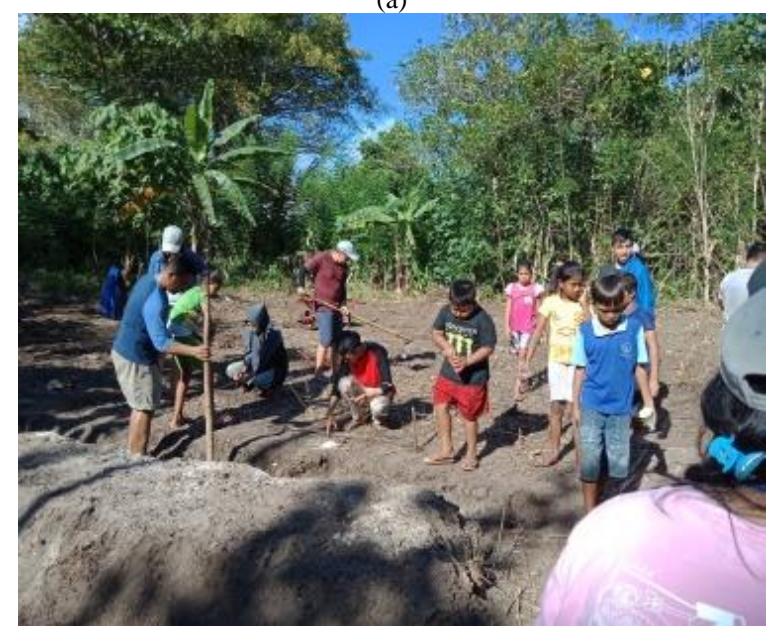

(b)

Gambar 5. Proses menanam bersama

\section{KESIMPULAN}

Berdasarkan hasil kegiatan dapat disimpulkan bahwa program Kuliah Kerja Nyata Pembelajaran Pemberdayaan Masyarakat (KKN PPM) di Talise telah berjalan dengan baik dan tujuan yang ditetapkan dapat tercapai. Hal ini dapat terlihat dari indikator ketercapaian:

a. Terlaksananya dan terfasilitasi kegiatan implementasi pengetahuan dan teknologi serta keterampilan budidaya tanaman pangan yang ditandai dengan tercipta usaha produktif tanaman jagung, kacang tanah dan tanaman sayuran, cabai, tomat untuk memenuhi kebutuhan konsumsi yang memanfaatkan halaman sekolah dan lahan masyarakat.

b. Terfasilitasi upaya peningkatan pengtahuan dan keterampilan pengolahan pupuk organik berbasis limbah pertanian dan kotoran ternak.

c. Terfasilitasi upaya peningkatan pengetahuan dan keterampilan masyarakat dalam usaha mengolah pakan ternak berbasis bahn baku lokal.

d. Terfasilitasi upaya pemanfaatan halaman sekolah di samping untuk kegiatan produksi juga menjadi media pembelajaran dan menanamkan jiwa kewirausahaan siswa serta sekaligus sebagai media pembelajaran scientific bagi mata pelajaran Ilmu Pengetahuan Alam di SMP Negeri 1 Likupang Barat.

e. Terfasilitasi upaya meningkatkan kesejahteraan petani melalui pemenuhan kebutuhan konsumsi pangan dalam upaya peningkatan pendapatan ekonomi keluarga.

\section{DAFTAR PUSTAKA}

Alma, B. (2013). Kewirausahaan. Bandung: Alfabeta.

Data Dinas Pendidikan. (2018). Kabupaten Minahasa Utara.

Maramis, A., Mege, R., Saerang, J., \& Manopo, J. (2016). Community empowerment through facilitation of rice field farming in Kabaruan Subdistrict, Talaud Islands, North Sulawesi. In: Soewandhi SN, Widnyana IK (eds) Innovation of Science and Technology of Higher Education to Improve the Prosperity of Society. In Proceedings of National Seminar on Results of Research and Community Service.

Mulyasa, E. (2008). Implementasi kurikulum tingkat satuan pendidikan: kemandirian guru dan kepala sekolah. Bumi Aksara.

Slameto. (2010). Belajar dan Faktor- Faktor yang Mempengaruhinya. Jakarta: Rineka Cipta. 